\title{
A Treaty-based framework for mainstream social work education in Aotearoa New Zealand: Educators talk about their practice
}

\author{
David McNabb, Unitec, Auckland, Aotearoa New Zealand
}

\begin{abstract}
INTRODUCTION: Globally, indigenous social work educators have pursued decolonisation and the development of decolonising practices as part of the indigenous peoples' rights movement and based on social work principles of self-determination and social justice. Māori have advanced decolonisation based on the original partnership that was envisaged in the Treaty of Waitangi signed between Māori and the British Crown in 1840. Aotearoa New Zealand social work education has a stated commitment to a Treaty-based partnership approach.

METHODS: This research engaged focus groups along with interviews of social work educators from nine of the 19 programmes across Aotearoa New Zealand to explore if, and how, this commitment to a Treaty-based approach was being demonstrated in the real world of practice. A diverse group of participants included Māori, Pākehā, Pasifika, and people identifying with other ethnic groups.
\end{abstract}

FINDINGS: Māori and non-Māori participants gave a range of perspectives relating to practising within a Treaty-based context. The Treaty should be understood historically but also in its contemporary expressions noting the extra demands placed on Māori. Non-Māori had an important role in demonstrating Treaty partnership and confronting White privilege. The Māori cultural approach of Kaupapa Māori was a foundation for a Treaty approach, and presented a challenge for non-Māori to learn this. A major challenge for programmes was having sufficient Māori staff.

Conclusions: Based on the findings, a Treaty-based teaching and learning framework has been developed to support educators as they advance decolonising practices and the indigenisation of social work education in Aotearoa New Zealand.

KEYWORDS: Social work education; Te Tiriti o Waitangi; decolonisation; Kaupapa Māori; White privilege

AOTEAROA NEW ZEALAND SOCIAL WORK 31(4), 4-17.

CORRESPONDENCE TO: David McNabb dmcnabb@unitec.ac.nz
He waka eke noa.

This whakata ukī (Māori proverb) has several meanings, one of which is "a canoe we are all in together."
In the context of this article on decolonising social work education, it is important to note that I identify myself as a non-indigenous Pākehā social work educator with British roots that go back to the arrival of my 
ancestors to Aotearoa New Zealand in 1843. Many people have contributed to my research and to the development of the ideas articulated in this article, in particular, Māori social work colleagues and others whose support and assistance is acknowledged below.

Social work and social work education trace their roots to Western cultures and paradigms. Born primarily in the context of industrialised countries including Britain and the USA, the expansion of formalised social work was largely influenced by British and American imperialism. Indeed, the forerunner to the International Association of Schools of Social Work began in seven European countries between 1928 and 1929, and spread beyond the West only after World War II (Healy, 2008). As such, it has developed a range of expressions of culturally responsive practice over time following global anti-oppressive social work traditions (Dominelli, 2002). These have included a range of responses such as radical social work, anti-racism social work, feminist social work, critical social work, green social work, decolonising social work and community development more generally. All embrace the core values and principles of social work which include respect, self-determination, social justice and human rights. Despite the profession's deep commitment to advancing these important principles, social work has nevertheless had a complex history with respect to indigenous peoples, often finding itself at odds with indigenous communities, particularly in the context of disadvantaged populations where social work has represented state welfare interests and expectations to the detriment of indigenous peoples (Connolly \& Ward, 2008).

Indigenous people have long fought for their rights and championed the establishment of the United Nations Declaration on the Rights of Indigenous Peoples (UNDRIP) (United Nations, 2008). This has formed part of the challenge to the profession of social work as a Western construct and its global alignment with Western hegemony and globalisation. Slow to respond, it was only in the 2014 revision of the definition of social work that indigenous knowledge was included and recognised as legitimate knowledge within the profession (International Federation of Social Workers (IFSW) \& International Association of Schools of Social Work (IASSW), 2014). Writers have argued that the experience of many indigenous social workers reflects a continuation of colonisation and its oppressive effect by the dominant West (Gray, Coates, Yellow Bird, \& Hetherington, 2016). Other countries and groupings of people from the global South and East have also resisted assimilation with the West (Sewpaul, 2014).

Frameworks supporting decolonising practice in social work education are established globally, such as in Australia with the Getting it Right framework (Zubrzycki et al., 2014), although they may not necessarily sit within regulatory systems. The Australian framework, while built on an explicit conceptualisation of knowing, being and doing linked to Aboriginal and Torres Strait Islander peoples (Martin \& Mirraboopa, 2003), was also informed by other indigenous models and broader social work approaches including community development and human rights-based perspectives. Other human service professions such as medicine have also addressed colonisation with a global indigenous led network calling for the decolonisation of medical education (Jones et al., 2019).

In Aotearoa New Zealand, Māori have pursued their indigenous rights and resisted colonisation with He Whakaputanga-the Declaration of Independence, signed by Northern Chiefs and recognised by the British in 1835 (Orange, 2015). Māori have asserted the primacy of the Treaty of Waitangi signed in 1840, particularly Te Tiriti o Waitangi (hereafter Te Tiriti), the version in the Māori language that most Māori leaders signed which more clearly affirmed the sovereignty of Māori as equal partners to the British (Orange, 2015). Te Tiriti held the 
vision of a mutually beneficial partnership and even of "bi-polity" where equitable governance could have been developed (Ruwhiu, Te Hira, Eruera, \& Elkington, 2016, p. 80). Part of the movement for addressing breaches of Te Tiriti are tribal settlements with the Government through the Waitangi Tribunal hearing process where a number of settlements have now been completed (Waitangi Tribunal, 2019).

Aotearoa New Zealand Association of Social Workers (ANZASW), the social work professional body for Aotearoa made a formal commitment to honouring Te Tiriti in 1992 (Nash, 2001) and has operationalised that commitment in various ways including a shared governance model between Māori and non-Māori beginning in the 1990s (McNabb, 2014). The ANZASW Practice Standards also incorporate this commitment (ANZASW, 2014). More recently ANZASW has changed the ANZASW Commitment to Biculturalism to the ANZASW Commitment to Te Tiriti o Waitangi within its ethical code to further emphasise the foundation provided by Te Tiriti (ANZASW, 2019). The Aotearoa tertiary education sector also has a broad commitment to aligning with principles of Te Tiriti and boosting the achievement of Māori (Ministry of Education \& Ministry of Business Innovation and Employment, 2014). Examples of Māori academic success include achieving the goal of 500 Māori PhD graduates in 2006 (Ngā Pae o te Māramatanga, 2019).

Honouring Te Tiriti requires a partnership approach where indigenous partners are recognised for their insider knowledge of the colonisation problem, alongside non-indigenous allies who are often the dominant majority and a key partner in creating change within conservative systems (Ruwhiu et al., 2016). This has become an imperative in Aotearoa New Zealand because of the deprivation experienced by Māori and their call for self-determination in finding solutions. It also invites major work by the non-indigenous partner to engage in decolonisation (Huygens, 2016).
One of the arguments made for adopting a Tiriti-based approach to education, which brings a Mãori approach alongside a Western approach, is that a holistic Māori approach is likely to benefit all learners as well as accelerating learning for groups such as Māori who may have traditionally done poorly within education. In research within a secondary education context, it was found that the holistic Māori approach within Kia Eke Panuku: Building on Success, led to improved outcomes for Māori and nonMāori alike (Berryman \& Eley, 2017).

There are a number of accounts of decolonising practice in social work education internationally, including the Hawai'i example where a whole social work department in a major university undertook the process of change (Morelli, Mataira, \& Kaulukukui, 2013). Other accounts include more personal stories of the journey by non-indigenous practitioners confronting the reality of racism, White privilege and general ignorance of indigenous histories and knowledge, in Australia (Gair, 2007) and in Aotearoa (Crawford, 2016). Research examining global and local social work education standards has found that there was a general affirmation of decolonising and democratising practices in both Australia and Aotearoa New Zealand (McNabb \& Connolly, 2019). However, the research noted that there was more that could be done to advance the goals of equity and social justice by regulatory authorities and the wider profession in advancing decolonisation and democratisation (McNabb, 2017). Further research in Aotearoa New Zealand has clearly illustrated the importance of leadership in advancing democratising and decolonising practices (McNabb, 2017).

Building on these earlier studies, this research explores how a stated commitment to a Tiriti-based approach is being operationalised by social work educators in their practice. From this, and insights from international research, a Tiriti-based framework for practice is presented. 


\section{Methods}

The study included qualitative focus groups and individual interviews with social work educators to investigate questions relating to decolonising practices in Aotearoa. Focus groups are a well-established approach within qualitative research (Barbour \& Morgan, 2017) as are individual interviews (Lichtman, 2014). These approaches allowed a more flexible and deeper conversation with educators exploring their daily experiences of promoting decolonising practices in social work programmes.

Social work educators from all 19 social work programme providers in Aotearoa New Zealand were invited to participate in the study ranging across university, polytechnic, and private institutional contexts. Unlike many other countries, Aotearoa allows for a range of tertiary education institutional contexts for social work education. A range of providers were engaged which gave a sector-wide spread of representation. Participants from nine of the 19 institutions were involved. This representation covered: Wānanga, polytechnic and university institutions; metropolitan and regional geographies; campus based and distance mediums; Māori, Pacific and mixed cultural settings; bachelor and masters level programmes; and small and large programmes. They represented a range of women and men of varying ages and experience in both practice and education; Pākehā, Māori, Pacific, African, and other European ethnicities were represented.

Numbers of participants in the focus groups varied, most had a minimum of three participants, while one had only two. There were seven focus groups conducted. Much of the literature talks about four being a minimum number for a focus group but others discuss the importance of the quality of what is shared as being more important (Liamputtong, 2011). Interviews were conducted with three people from different programmes due to insufficient numbers being available to make up a focus group.

Most focus groups and interviews were conducted using online synchronous digital technology through the Blackboard Collaborate platform or through Skype with a minority of interviews conducted in person. A semi-structured schedule of questions was used that included themes from previous document analysis, specifically relating to "service user and student participation, student representativeness, indigenous rights and political action, gender and cultural equity, access and equity, and quality social work education and broader issues of equity" (McNabb \& Connolly, 2019, p. 8). Participants were asked to what extent and in what way the themes were evident in their programme. The data were analysed thematically using the NVivo data analysis software tool. Quotes reference whether a focus group or an individual participant was involved and use numbering to account for all contributors.

Ethics approval was gained and the study was regarded as a minimal risk project by the Human Ethics Advisory Group of the University of Melbourne; approval number 1748887. All participants in the study gave informed consent. A Māori Reference Group included three senior Māori leaders, and was engaged for consultation at key points of the research including ethics approval and for the initial research-based publications. Consultation was also sought for key publications with experienced Māori social workers. Indigenous researchers have criticised the effect of colonisation on indigenous people and on the research approaches that have been used to study them (Tuhiwai Smith, 2012). As noted, I identify as Pākehā (European ethnicity, non-Māori) and have been working with Māori participants in this research as well as exploring themes of colonisation in the knowledge that I am linked to the dominant Pākehā group. Engaging with the Māori Reference Group supported me in 
working more effectively with decolonising methodologies and directly with Māori participants. An example of this practice is Te Kāhui Kaihautū, the Māori Reference Group for the research organisation, the New Zealand Institute of Language, Brain and Behaviour (2016).

There are a number of limitations relating to this research. The research explores the views of participant social work educators and cannot be generalised more broadly across the whole group of social work educators in Aotearoa New Zealand. Nor does the research include the voices of students or people who represent the wider social work sector including service users, iwi and Māori organisations, community organisations and other stakeholders such as government. Also of note is that the research is a doctoral study and, although a Māori Reference Group was engaged for consultation, I have undertaken this research as a sole researcher, and have not engaged with a Māori partner as might otherwise be indicated given the theme of Tiriti-based partnerships. The findings, and also the framework developed later in the article, are therefore limited in this regard. The framework is presented in order to encourage further debate and action on ways in which non-Mãori social work educators might advance a Tiriti-based approach. Future research and practice development would indicate a partnership approach was essential.

\section{Findings}

Social work educator participants are at the frontline of teaching and learning, interacting with students on a daily basis. They highlighted the overall challenge of operationalising a commitment to Te Tiriti in practice.

The findings have been gathered under the headings of: Ngā Mōhiotanga-knowing; Ngā Whakaahuatanga—being; and Te Whakatinanatanga-doing. The frame of knowing, being, and doing resonates with conceptualisations of indigenous research and practice within the Australian context (Martin \& Mirraboopa 2003) and, in particular, with the findings of the study, as participants spoke about "doing, understanding, knowing and being Māori" (Focus Group 5).

\section{Ngā Mōhiotanga-knowing: Understanding Te Tiriti and Kaupapa Māori}

All programmes expressed a commitment to honouring Te Tiriti and its expectations with respect to partnership and self-determination for Māori. It is a broad-based commitment that can be expressed in many ways. It links to many other expressions of inequity such as poverty and its disproportionate rate amongst Māori, and it relates to having a deep knowledge of, and commitment to, decolonising practices. Educators noted that developing a depth of understanding of Te Tiriti and Kaupapa Māori involves people in an ongoing process of learning: "How we're committing to Treaty principles? It's a work in progress" (Focus Group 1).

Educators also appreciated the dynamic nature of culture-it is not static and unchanging. Rather, it adapts and responds to contemporary contexts, requiring continual engagement and development of new understandings. Some Māori staff in particular made a plea for staff and students to be aware of this dynamic context of Te Tiriti settlement and support for ongoing political change:

Just linking the work politically in terms of Te Tiriti o Waitangi and continuing to do that; especially as we're going into post-settlement ... Things are changing very quickly in terms of tangata whenua [people of the land] and it's getting people to move forward with us and not keep us back in the past. (Focus Group 7)

Hence, Te Tiriti has contemporary expression in the settlement process and the way in which many hapū (sub-tribes) and iwi 
(tribes) are undergoing development in this post-settlement phase. Along with understanding issues for Māori historically and the contemporary issues arising from this, an understanding of the extra demands that Māori face from their whānau (family) and hapori (community) were considered to be important for both Māori students and staff. Understanding the cultural demands for students and how these impact on dynamics in the classroom was noted: "You see with the Māori students, the extra demands that are placed upon them, in terms of family whānau commitments" (Participant 3).

Understanding cultural dynamics operating in the classroom was also seen as critical. For example, educators spoke of Māori staff and students experiencing racism and discrimination and the need for cultural safety practices across the programme:

You know, I've got to be honest; I have experienced institutional racism as a tangata whenua and Māori practitioner and lecturer ... from a staff point of view, but also a student point of view ... I mean, that's a reality for them-not just within this institute but externally as well. (Focus Group 7)

The employment of Māori staff brought an essential and critical contribution to the programme:

I think we are quite lucky here in that for 20 years we've had at least two or three Māori staff and we've had amongst the rest of the staff cohort, a commitment to doing, understanding, knowing and being Māori. (Focus Group 5)

Educators also noted, however, the importance of having non-Māori staff both knowledgeable and committed to a Tiriti partnership approach. While they saw Māori staff as having the primary engagement with respect to teaching Te Tiriti and Māori knowledge, they saw non-Māori staff as having a role as allies and partners in the building of a Te Tiriti-based approach.
At the same time, non-Māori recognised the limitations of their competence and questioned the appropriateness of teaching and assessing the competence of students to practise social work with Māori: "Is it ... appropriate for me, as [a] Tauiwi [nonMāori] educator, to then be teaching Māori knowledge? ... we don't want to overly rely on our Māori colleagues" (Focus Group 1). Nonetheless, non-Māori staff were seen to have a role in both understanding and advancing Māori knowledge in the programme and, in particular, having a responsibility to teach about White privilege and racism amongst other structural themes, and to ensure students demonstrated this knowledge in their learning and practice: "Then there are things like teaching about White privilege, which they [Māori staff] don't see as their responsibility; it is our [non-Māori staff] responsibility to teach that" (Participant 4).

\section{Ngā Whakaahuatanga-being: Integrating a Tiriti-based programme identity}

Participants suggested that becoming knowledgeable about Te Tiriti and Kaupapa Māori and understanding its impact in contemporary contexts represents the beginning of a process of developing a Tiritibased programme identity. Internalising the knowledge base does not always come easy. Indeed, some programmes noted a minority of students who were taking time to be open to the message about Te Tiriti and to cultural responsiveness with Māori.

One of the principles of Te Tiriti is sharing power between Māori and non-Māori based on rights that Māori have. Appreciating that there is a difference between knowing about Kaupapa Māori and actually integrating this knowledge as a fundamental aspect of programme identity was noted:

One of the critical things about this for us is, just because people are welleducated in regards to the Treaty and they have understandings of things like 
human rights and social justice, it does not ensure they share power with Māori. (Focus Group 5)

Students can learn this, and learn how it can inspire political action. Educators saw this as important learning within programmes, as well as being publicly activated by staff. This was seen as requiring appropriate knowledge by staff about Te Tiriti and the skill to support this type of student learning and action.

Strengthening Pākehā responsibility for teaching Te Tiriti and a partnership approach requires in-depth integrated knowledge, and some programmes highlighted the efforts non-Māori staff had gone to in strengthening their identification with cultural change. At the same time, Māori staff have to make choices about how their identity is expressed in mainstream social work programmes. It was acknowledged as complex when they attempt to engage in a Kaupapa Māori way:

They ask, "Are you a Māori social worker or are you a social worker who's Māori?" That is the question, because one would attribute to mainstream thinking and the other would attribute to pedagogy Māori ... thinking. (Focus Group 9)

Students from the Pacific or other migrant ethnic groups who do not identify as Māori or Pākehā often struggle with their relationship to Te Tiriti and indigenous rights. Staff were nevertheless seen as important contributors to complex cultural identity discussions. At the same time, it was considered important that students and staff with migrant experience be supported to claim a safe migrant space, "where we can talk about settling in and finding resources" (Focus Group 10).

The strength of a programme's integrated Tiriti identity varied, which was something that Māori students sought advice from Māori staff about, particularly when considering which programme to apply for. Appreciating that not all programmes provide the depth of Kaupapa Māori teaching that may be sought, a student could be guided toward a programme offering a better cultural fit:

In terms of the student make-up there are some students that come to us with particular requests ... [we may] send them somewhere else, because they particularly, or strongly want to work with hapū [Māori sub-tribes]; ... they want their starting point for learning and interpreting to be Māori. (Focus Group 5)

The Wānanga (Māori-based education institution) is, arguably, most likely to have the strongest Tiriti identity, providing a more solid base for teaching Māori knowledge and practice than mainstream institutions. This raised questions for some educators about the degree to which mainstream programmes can fully integrate a Kaupapa Māori identity: "And so, if you think about the Wānanga, the likes of Raukawa and Aotearoa, their starting [point] for understanding is te ao Māori [the Māori world]" (Focus Group 5). This is not necessarily the case for mainstream programmes, where the degree to which they are able to integrate a Tiriti identity also depends upon their ability to employ sufficient Māori staff.

In practical terms, participants spoke about the struggle to recruit and retain Māori social work academics. Although external Māori experts could be contracted in, non-Māori staff saw the importance of partnership relationships for effective teaching. Non-Māori have a role in supporting Māori workforce development and in sharing Te Tiriti-based partnership responsibility in the programme. Some were critical of the standards set by the Social Workers Registration Board (SWRB) especially the requirement for a master's level qualification which excluded many Māori staff, ultimately impacting on their ability to advance an integrated Tiriti identity: "I don't know why Māori are not applying, but it's also restricted by the 
SWRB requirements and I think that's the biggest [reason] ... we've [also] lost staff because of that" (Focus Group 2).

\section{Te Whakatinanatanga-doing: Operationalising Te Tiriti and Kaupapa Māori in practice}

Giving effect to bicultural practice in the classroom was seen as complex by many participants, particularly in mainstream programmes. Educators expressed some of the challenges: "Our bi-culturalism course ... there's always sort of a fear from teachers around teaching this course. It's one of the hard ones ... students feel uncomfortable, and they give poor evaluations" (Participant 6).

Within this dynamic teaching environment, teaching staff need to have a deep understanding of, and confidence in, engaging with the ideas, and be skilled facilitators who are able to manage "hard conversations in the classroom." Te Tiriti provides a base for addressing indigenous justice which can then be applied across a range of equity issues: "I think, irrespective of the issue with gender, ethnicity, socio economic ... once you've applied the framework with the students once ... it's far easier for them to see it in other areas" (Focus Group 9).

Te Tiriti itself is a major topic for study, along with the context of colonisation and its negative effect on Māori. Moving beyond the basics, developing an advanced course on Te Tiriti was seen as a sign of leadership and solidarity by staff. In addition, having a specific focus on Te Tiriti, and embedding Māori culture across the programme was seen as a way of integrating Māori culture and knowledge more thoroughly and also for gaining feedback for programme improvement:

I think in addition to that specific cultural context stream ... we also try and embed te reo Māori [Māori language] in all the other subjects, as much as we can. So, every single day we have karakia [prayer] and waiata [singing], and finish [with] the karakia. (Focus Group 1)

Integrating Māori approaches and Western bodies of knowledge was also seen as a way to learn Māori knowledge while, at the same time, helping to meet the social work professional obligation of Tiritibased practice aligned with the ANZASW Code of Ethics (2019): "In my programme of sociology and psychology ... [what] I've been excited about is ... developing an understanding about different Māori models" (Focus Group 9).

Some staff were using theories of intersectionality, which interrogates how multiple oppressions interact and accumulate harm for those with related multiple identities, alongside the relevant dimensions of privilege (Almeida, Werkmeister Rozas, Cross-Denny, Lee, \& Yamada, 2019). This was seen as a means through which this blending of knowledges could occur:

I would say that certainly the dynamic in this country is far dominated by culture, and I think that the feminism and the class issues are embedded within [this] ... I think we've got a course at first year level which unpacks intersectionality really well, and gets students to do the sort of "ko wai au?" self-identification and location (Focus Group 8).

Pacific and Māori participants wove Pacific and Māori models alongside critical Western models in their teaching:

This year for research methods, I decided to not include the Pasifika and Māori models but to focus on emancipating post-modern and feminist research; because I had a feeling that the students were thinking that the Brown models were weak links and we weren't but of course emancipating post-modernist and feminist research led us all the way back to being Māori, Pacific and Aotearoa New Zealand. (Focus Group 9) 
Educators also spoke of a range of initiatives that have been shown to support Māori students. These often involve Māori staff and senior Māori students mentoring other students and using culturally rich ideas and processes. This cultural richness helps to bring holistic responses to the person and their issues within the context of family and community: "I'm part of the faculty Māori advancement group. We meet once a month, and we talk about Māori student retention, and ways of encouraging Māori mentorship, and growing Māori post-graduate students" (Participant 3).

Overall, educators considered programme leadership to be critical in driving Kaupapa Māori, particularly where non-Māori show courage to act and Māori staff are respected for their position and unique contribution:

It's imperative that you have a senior right up the very top level of support for this; it's too hard otherwise. And, our senior academics behind us as well, our academic leads ... I also want to acknowledge how we have to have courage when we go into cultural space ... our colleagues are having those courageous cultural conversations with us [and] also respecting our status as tangata whenua. (Focus Group 7)

\section{Discussion}

Indigenous voices have raised major questions about how well Westernrooted social work can ever form an equitable partnership with indigenous knowledges and practices (Gray et al., 2016). The effects of colonisation are pervasive and the contemporary context of neoliberalism and globalisation only serve to strengthen Western pedagogies. Even when members of the dominant group are committed to change there seems to be a myriad of obstacles that get in the way of operationalising such a commitment. Indigenous social work educators nevertheless continue to pursue an equitable partnership as a matter of self-determination and supporting the principle of social justice. Non-indigenous social work educator allies also remain committed to the challenge and to the invitation by indigenous colleagues to partner in this cause.

The findings of this study highlight the challenges and rewards of developing culturally responsive practices in social work education. The key terms: Ngā Mōhiotanga—knowing, Ngā Whakaahuatanga-being, and Te Whakatinanatanga-doing, that relate to understanding, integrating and operationalising Te Tiriti, present an important and strongly aligned conceptualisation of the issue from the perspectives of the participants in this study. These findings have now been incorporated into the following framework (Figure 1) that serves to privilege a Māori ontology in ways that challenge colonialism, racism and White privilege, and respectfully builds more culturally responsive practices.

\section{Honouring Te Tiriti partnership}

Te Tiriti is at the centre of the "authorising environment" for a culturally responsive approach to social work education in Aotearoa New Zealand (McNabb \& Connolly, 2019). The central place of Te Tiriti is also evidenced within institutional policies and charters (see for example, Te Noho Kotahitanga (Unitec Institute of Technology, 2001)). ANZASW, the social work profession, has had a constitutional commitment to upholding Te Tiriti since 1992 (Nash, 2001), and the SWRB includes a commitment to Te Tiriti in its Programme Recognition Standards (Social Workers Registration Board, 2018). The SWRB also initiated a consultation process on the expression of Te Tiriti within its practice standards which yielded the draft policy Kaitiakitanga Framework (Social Workers Registration Board, 2016b).

Having enough Māori staff remains a priority issue for many programmes, as noted in the findings, and is a critical 


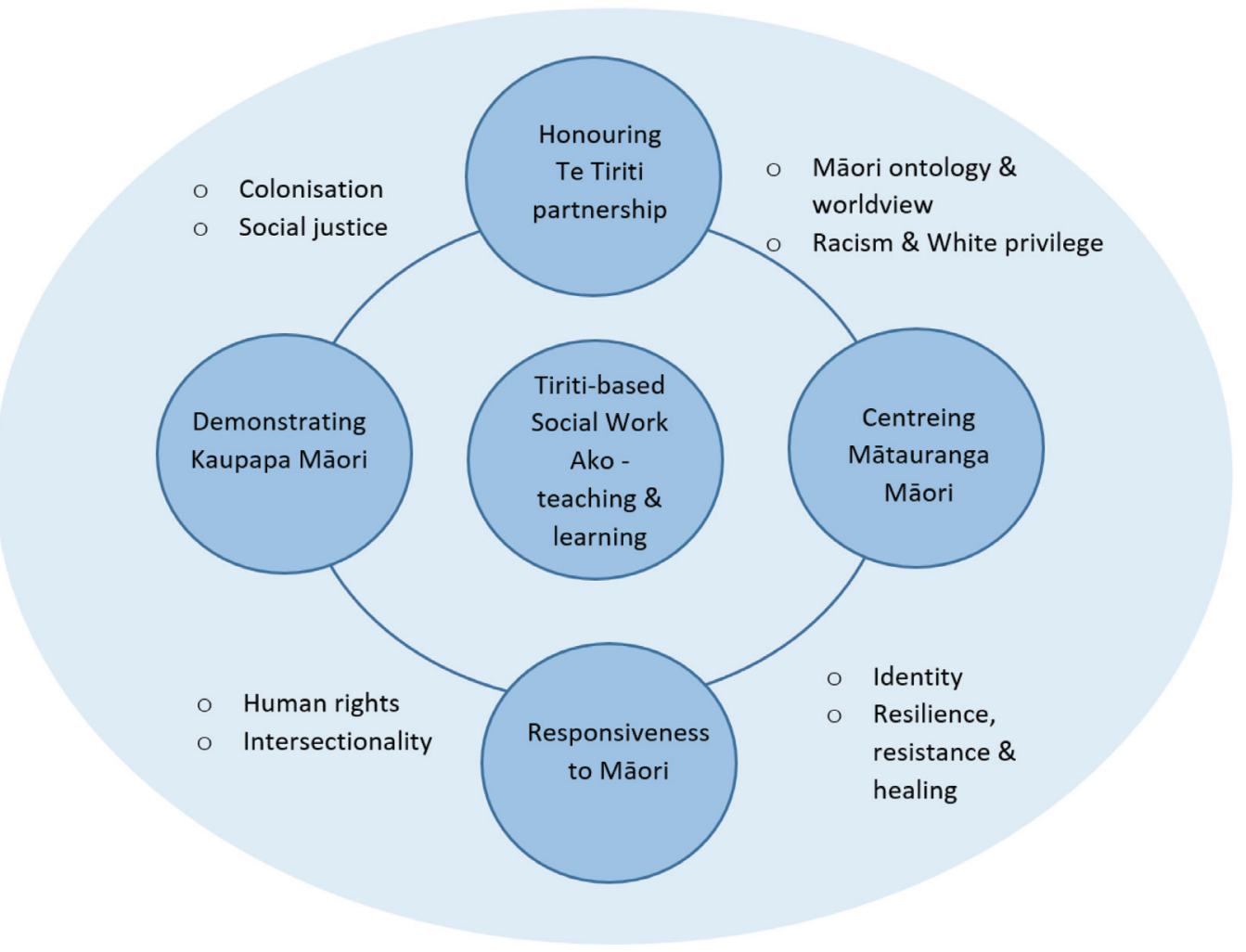

Figure 1. Framework for Tiriti-based social work: Ako-teaching and learning.

component of a Tiriti-based programme. However, changes to the standards requiring all social work academic staff to have completed a master's qualification for teaching on a bachelor-level programme signaled a barrier to Māori staff in particular, as a number were either yet to start a masters or were needing more time to complete it. This led to the Council for Social Work Educators in Aotearoa NZ (CSWEANZ) to write and ask for more flexibility on this requirement with the suggestion that each programme could have one position where a staff member with key Māori, Pacific or fieldwork knowledge was in the process of completing their master's qualification (CSWEANZ, personal communication, August 5, 2017). However, the SWRB declined this request saying that these staff could be hired in a tutorial-type role and not have full responsibility for core social work courses (SWRB, personal communication, October 6, 2017). CSWEANZ remained unsatisfied and the problem of hiring enough Māori staff continues.

This broad-ranging commitment to honouring Te Tiriti influences all dimensions of the Framework for Tiriti-based Social Work, supporting the criticality of partnership between Māori and Tangata Tiriti (non-Māori Tiriti partners) in all aspects of practice. Honouring Te Tiriti is aligned with the social work commitment to social justice, human rights and the validity of indigenous knowledge (IFSW \& IASSW, 2014). This is very much a dynamic process that will be inherently challenging given its relational context and the structural disjuncture between the colonised and the coloniser. The tension and potential within this process has been termed the " $3 \mathrm{rd}$ cultural space" based on Bhabha's theory of culture (1994, cited in Zubrzycki et al., 2014). It speaks to the space where "new knowledge, insights and understandings about identity and positioning emerge" (p. 19). 


\section{Centring Mātauranga Māori}

Centring Mātauranga Māori (Māori knowledge) and de-centring Western knowledge is a critical component of the Framework. Participants in the research frequently spoke of their own experience of this process as the use of Mātauranga Māori is ubiquitous across education in Aotearoa New Zealand, though at varying levels of strength. Mātauranga Māori was embedded in education legislation in 1989 to support new kura kaupapa (Māori language medium schools) linked to government obligations under Te Tiriti (Calman, 2019). This plays out operationally in a number of particular ways. Within the tertiary education context, there is a range of government policies of relevance including the strategy for developing Māori success, Ka HikitiaAccelerating Success 2013-2017 (Ministry of Education, 2013). The government also funds Ako Aotearoa, an organisation which supports tertiary educator practice development to ensure students' success, with a priority of Māori student success.

The term epistemological equality (Zubrzycki et al., 2014, p. 17) is one of four key concepts in the Getting it Right Framework and has been used as a way to talk about how two sets of knowledges can be applied within a learning context. This sits within the notion of ontology, one of 10 key dimensions used in the Getting it Right Framework, where it relates to what is believed to be real, whereas epistemology relates to ways of thinking about that reality (Zubrzycki et al., 2014). Holding two sets of knowledges aligns well with the partnership spirit of Te Tiriti. The fact that indigenous and Westernbased knowledge come from two different paradigms nevertheless highlights the challenge in incorporating these different knowledges in an equivalent way, also noted in other cultural contexts such as the Pacific with its varying epistemologies. As such, the joining of two sets of knowledge across the whole curriculum will avoid the risk of indigenous knowledge being an addon or treated as a minor or less important area of learning. As a way of exposing the dominance of Western knowledge, it is an important aspect of addressing colonisation and racism. Zubrzycki et al. (2014) proposes that Whiteness theorising is vital to this process of supporting non-indigenous students to recognise the privileges of being White and/or non-indigenous to help set up more respectful and collaborative relationships with indigenous people.

\section{Demonstrating Kaupapa Māori}

This dimension examines the Māori cultural values and practices that support teaching and learning Mātauranga Māori. This demonstrates rangatiratanga (selfdetermination) and the right of Māori to determine what and how Māori knowledge and culture should be taught. As with the other dimensions, Kaupapa Māori principles can operate alongside good Western educational principles. The Hei Toko research report found that "good Kaupapa Māori based practice needs to be learner centred, whole-of-organisation, dynamic, responsive and highly adaptive" (Apanui \& Kirikiri, 2015, p. iv). They identified six components of a Kaupapa Māori model: Whakamana (empowerment), Ako (holistic teaching and learning), Te Tiriti o Waitangi (dual governance), Manaakitanga (care and support), Whanaungatanga (building relationships), and Kotahitanga (collaboration).

Demonstrating Kaupapa Māori practice can be a challenge, particularly so for nonindigenous lecturers when it represents a weakness in their knowledge base requiring focused development, and is often part of a broader decolonisation process (Apanui \& Kirikiri, 2015).

More recently, the government tertiary quality assurance body for non-university institutions launched a Kaupapa-Māoribased framework, Te Hono o Te Kahurangi Evaluative Quality Assurance (New Zealand Qualifications Authority, 2017). This principle-based approach privileges Māori 
responses to tertiary quality assurance with a focus on Māori-based institutions, but also looks to mainstream institutions wanting to improve Kaupapa Māori in practice.

\section{Māori practice responsiveness}

Cultural competence has been frequently used as a term to describe the way in which people practise respectfully and with relevance to people from diverse cultures. Competencies is the language used by the SWRB for social work practitioners in describing expectations of their practice with service users (SWRB, 2016a). Cultural responsiveness is nevertheless emerging as a more helpful term that speaks both to the ability to develop collaborative relationships with people and to critically reflect on one's own positioning and the structural context in which practice occurs (Connolly, Crichton-Hill, \& Ward, 2006; Zubrzycki et al., 2014). I have used the term Māori practice responsiveness in the framework to focus specifically on this aspect of critical reflexivity and to emphasise the importance of "building culturally responsive practices that resonate with the world of Māori" (Ruwhiu, 2017, p. 107). As noted earlier, intersectionality is a helpful tool for critically engaging with the differences within groups as well as between groups that addresses other dimensions of oppression and privilege such as gender, sexuality, class, ability and age among others. The goal for social work being anti-oppressive and anti-privilege based education and practice (Mullaly \& West, 2018).

A focus on identity is important for both students and educators. Whereas Te Tiriti brought two parties together as tangata whenua (literally people of the land) and tangata Tiriti (literally people of the Treaty, non-Māori represented by the British signatory of Te Tiriti), the breaching of Te Tiriti and the effects of colonisation mean both parties are located in a social and structural arrangement of ongoing oppression for Māori that has created challenges for embracing both Māori and non-Māori identities. Māori have a right to be fully Māori, and non-Māori, including White people, have a responsibility to address colonial and White privilege that comes with their identity and position. Stories of Māori resilience and resistance form important knowledge for both partners to hold and is a prerequisite to developing a more equitable relationship with the prospect of healing for Māori and a healing of the breach of partnership that was originally promised in the signing of Te Tiriti.

\section{Conclusions}

Te Tiriti o Waitangi is the founding document for Aotearoa New Zealand and provides an authorising environment for those wanting to build their practice on Te Tiriti (McNabb, 2019). It has been embraced by various fields of practice, including the education sector and the social work profession, as the cornerstone for their activities. The global movement for indigenous rights provides a vital backdrop for the Aotearoa context, and there are strong parallels with the global initiative to decolonise education across health and human services, including social work.

The social work education sector has committed itself to honouring Te Tiriti but the findings of this research suggest that it is challenged in its efforts in a number of areas. The Framework for Tiriti Based Social Work: Ako_-Teaching and Learning, has been presented as a way to assist social work education on its decolonising journey, through further debate and action. Offering an organising construct for social work education and its allies within Aotearoa New Zealand, it supports a movement for change and contributes to the global mission of decolonisation.

\section{Acknowledgments}

I wish to thank social work education colleagues across the country who were willing to participate in the research. In addition, I acknowledge the many people who have generously contributed to the development of 
the ideas articulated in this article, in particular Māori social work colleagues, and especially Shannon Pakura and Sharyn Roberts who provided feedback on drafts. I wish also to acknowledge the contributions of Te Hau Hona (Kaihautu) and Chance Taylor (Taura Here Support) from my institution, the Unitec Institute of Technology, Auckland for the Māori wording for knowing, being and doing. I am deeply indebted to Professor Marie Connolly who has supported my research and has assisted in the development of this article. As sole author and researcher, however, I take full responsibility for the work reported and written.

\section{References}

Almeida, R. V, Werkmeister Rozas, L. M., Cross-Denny, B., Lee, K. K., \& Yamada, A. M. (2019). Coloniality and intersectionality in social work education and practice. Journal of Progressive Human Services, 30(2), 148-164. Retrieved from http://10.0.4.56/10428232.2019.1574195

Aotearoa New Zealand Association of Social Workers. (2014). ANZASW social work practice standards. Retrieved from http://anzasw.nz/wp-content/uploads/ Practice-Standard-Publication-Full-Nov-14.pdf

Aotearoa New Zealand Association of Social Workers. (2019). ANZASW code of ethics. Retrieved from https://anzasw.nz/wp-content/uploads/Code-of-EthicsAdopted-30-Aug-2019.pdf

Apanui, N., \& Kirikiri, T. (2015). Hei toko i te tukunga: Enabling Màori learner success. Kaupapa Màori learnercentred education practice. Retrieved from https://ako.ac.nz/assets/Knowledge-centre/Hei-toko/ a8150a3fb5/RESEARCH-REPORT-Hei-Toko-i-TeTukunga-Enabling-Māori-Learner-Success.pdf

Barbour, R. S., \& Morgan, D. L. (2017). A new era in focus group research: Challenges, innovation and practice. London, United Kingdom: Palgrave Macmillan.

Berryman, M., \& Eley, E. (2017). Accelerating success and promoting equity through the Ako: Critical contexts for change. Asian Education Studies, 2(1), 99-112. https://doi.org/10.20849/aes.v2i1.126

Calman, R. (2019). Māori education-mātauranga-Māori education policy. Retrieved from http://www.teara.govt. nz/en/Māori-education-matauranga/page-7

Connolly, M., Crichton-Hill, Y., \& Ward, T. (2006). Culture and child protection: Reflexive responses. London, UK: Jessica Kingsley Publishers.

Connolly, M., \& Ward, T. (2008). Morals, rights and practice in the human services: Effective and fair decision-making in health, social care and criminal justice. Philadelphia, PA: Jessica Kingsley.

Crawford, H. (2016). A Pākehā journey towards bicultural practice through guilt, shame, identity and hope. Aotearoa New Zealand Social Work, 28(4), 80-88. https://doi.org/http://dx.doi.org/10.11157/anzswjvol28iss4id300
Dominelli, L. (2002). Anti-oppressive social work theory and practice. New York, NY: Palgrave Macmillan.

Gair, S. (2007). Pursuing Indigenous-inclusive curriculum in social work tertiary education: Feeling my way as a non-indigenous educator. Australian Journal of Indigenous Education, 36, 49-55. Retrieved from https://search-informit-com-au.ezp.lib.unimelb.edu.au/do cumentSummary;dn=895395468180036;res=|ELIND> ISSN: 1326-0111

Gray, M., Coates, J., Yellow Bird, M., \& Hetherington, T. (2016). Decolonizing social work. London, UK: Routledge. https://doi.org/10.4324/9781315576206

Healy, L. (2008). Introduction: A brief journey through the 80 year history of the International Association of Schools of Social Work. Social Work \& Society, 6(1), 115-127. Retrieved from https://socwork.net/sws/article/ view/98/160

Huygens, I. (2016). Pākehā and Tauiwi Treaty education: An unrecognised decolonisation movement? Kotuitui, 11(2), 146-158. https://doi.org/10.1080/117708 $3 \mathrm{X} .2016 .1148057$

International Federation of Social Workers (IFSW) \& International Association of Schools of Social Work (IASSW). (2014). Global definition of social work and commentary. Retrieved from http://ifsw.org/get-involved/ global-definition-of-social-work/

Jones, R., Crowshoe, L., Reid, P., Calam, B., Curtis, E., Green, M., ... Ewen, S. (2019). Educating for indigenous health equity: An international consensus statement. Academic Medicine, 94(4), 512-519. https://doi.org/10.1097/acm.0000000000002476

Liamputtong, P. (2011). Focus group methodology: Principles and practice. London, United Kingdom: SAGE Publications. https://doi.org/10.4135/9781473957657

Lichtman, M. (2014). Qualitative research for the social sciences. London, UK: SAGE Publications. https://doi.org/10.4135/9781544307756

Martin, K., \& Mirraboopa, B. (2003). Ways of knowing, being and doing: A theoretical framework and methods for indigenous and indigenist re-search. Journal of Australian Studies, 27(76), 203-214. https://doi.org/10.1080/14443050309387838

McNabb, D. (2014). 30 years' membership and a 50th birthday-where to next for ANZASW? Aotearoa New Zealand Social Work Review, 26(2\&3), 61-71. https://doi.org/http://dx.doi.org/10.11157/anzswjvol26iss2-3id43

McNabb, D. (2017). Democratising and decolonising social work education: Opportunities for leadership [online]. Advances in Social Work and Welfare Education, 19(1), 121-126. Retrieved from https://search-informit-com-au. libproxy.unitec.ac.nz/fullText; dn=054345135195632; res=IELHSS

McNabb, D. (2019). Decolonising social work education in Aotearoa New Zealand. Advances in Social Work and Welfare Education, 21(1), 35-50. Retrieved from https://search-informit-com-au.libproxy.unitec.ac.nz/ documentSummary; $\mathrm{dn}=530132370083635$; res=IELHSS

McNabb, D. J., \& Connolly, M. (2019). The relevance of global standards to social work education in Australasia. International Social Work, 62(1), 35-47. https://doi.org/10.1177/0020872817710547 
Ministry of Education. (2013). Ka hikitia: Accelerating success/Māori education strategy 2013-2017. Retrieved from http://www.education.govt.nz/assets/ Documents/Ministry/Strategies-and-policies/Ka-Hikitia/ KaHikitiaAcceleratingSuccessEnglish.pdf

Ministry of Education, \& Ministry of Business Innovation and Employment. (2014). Tertiary education strategy 2014-2019. Retrieved from https://education.govt.nz/ assets/Documents/Further-education/Tertiary-EducationStrategy.pdf

Morelli, P. T., Mataira, P. J., \& Kaulukukui, C. M. (2013). Indigenizing the curriculum: The decolonization of social work education in Hawai'i. In T. Hetherington, M. Gray, J. Coates, \& M. Y. Bird (Eds.), Decolonizing social work (pp. 207-222). Farnham, UK: Ashgate Publishing.

Mullaly, R. P., \& West, J. (2018). Challenging oppression and confronting privilege: A critical approach to antioppressive and anti-privilege theory and practice (3rd ed.). Don Mills, Ontario: Oxford University Press.

Nash, M. (2001). Social work in Aotearoa New Zealand: Its origins and traditions. In M. Connolly (Ed.), New Zealand social work: Contexts and practice (pp. 32-43). Melbourne, Australia: Oxford University Press.

New Zealand Institute of Language Brain and Behaviour. (2016). Te Kāhui Kaihautū, The Māori reference group. Retrieved from http://www.nzilbb.canterbury.ac.nz/ tekahui.shtml

New Zealand Qualifications Authority. (2017). Guidelines for Te Hono o Te Kahurangi evaluative quality assurance. Retrieved from https://www.nzqa.govt.nz/Māori-andpasifika/te-hono-o-te-kahurangi/

Ngā Pae o te Māramatanga. (2019). Producing 500 new Māori PhDs in five years. Retrieved from http://www. maramatanga.co.nz/news-events/news/producing-500new-māori-phds-five-years

Orange, C. (2015). The story of a Treaty (2nd ed.). Wellington, New Zealand: Bridget Williams Books.

Ruwhiu, L. (2017). Making sense of indigenous issues in Aotearoa New Zealand. In M. Connolly, L. Harms, \& J. Maidment (Eds.), Social work: Contexts and practice (4th ed., pp. 95-108). South Melbourne, Victoria: Oxford University Press.

Ruwhiu, L., Te Hira, L., Eruera, M., \& Elkington, J. (2016). Borderland engagements in Aotearoa New Zealand: Te Tiriti and social policy. In J. Maidment \& L. Beddoe (Eds.), Social policy for social work and human services in Aotearoa New Zealand: Diverse perspectives (pp. 79-93). Christchurch, New Zealand: Canterbury University Press.

Sewpaul, V. (2014). Social work education: Current trends and future directions. In C. Noble, H. Strauss, \& B. Littlechild (Eds.), Global social work: Crossing borders, blurring boundaries (pp. 353-367). Sydney, NSW: Sydney University Press.

Social Workers Registration Board. (2016a). Core competence standards. Retrieved from https://swrb.govt $\mathrm{nz} /$ for-social-workers/core-competence-standards/

Social Workers Registration Board. (2016b). Kaitiakitanga framework. Retrieved from https://swrb.govt.nz/about-us/ news-and-publications/publications/

Social Workers Registration Board. (2018). Programme recognition standards. Retrieved from http://swrb.govt. nz/about-us/policies/
Tuhiwai Smith, L. (2012). Decolonizing methodologies: Research and indigenous peoples. (2nd ed.). London, England: Zed Books.

Unitec Institute of Technology. (2001). Te Noho Kotahitanga. Retrieved from https://www.unitec.ac.nz/about-us/tenoho-kotahitanga-and-unitec

United Nations. (2008). United Nations declaration on the rights of indigenous peoples. Retrieved from http://www. un.org/esa/socdev/unpfii/documents/DRIPS_en.pdf

Waitangi Tribunal. (2019). Meaning of the Treaty. Retrieved from https://www.waitangitribunal.govt.nz/treaty-ofwaitangi/meaning-of-the-treaty/

Zubrzycki, J., Green, S., Jones, V., Stratton, K., Young, S., \& Bessarab, D. (2014). Getting it right: Creating partnerships for change. Integrating Aboriginal and Torres Strait Islander knowledges in social work education and practice. Teaching and learning framework. Sydney, NSW: Australian Government Office for Learning and Teaching. 